\title{
Ornithology on the island of Helgoland and the role of the Biologische Anstalt up to the foundation of the separate "Vogelwarte"
}

\author{
Ch. Hünemörder \\ Institut für Geschichte der Naturwissenschaften, Mathematik und Technik der Univer- \\ sität Hamburg; Bundesstraße 55, D-20146 Hamburg, Germany
}

The enormous number of transmigrating and breeding birds on Helgoland had for hundreds of years been the major source of food for the inhabitants of the formerly Danish island (Stresemann, 1967). At the beginning of the 19th century, many natural history collections were established in Europe, and with this an interest in bird taxidermy developed. After the occupation of the island by the British in 1807, an island craftsman, Erich J. Koopmann ( $\dagger$ 1835), around 1820, began collecting skins for a number of museums. Visiting scientists (Stresemann, 1967, p. 421) like Johann Friedrich Naumann (1780-1857), drew attention to Helgoland, which had slowly been developing into a seaside resort since 1826; the island now became very popular among ornithologists. Even the secretary to the British Governer and well-known painter of seascapes Heinrich Gätke (1814-1897) - a resident of Helgoland since 1837 - could not resist the attraction of ornithology. He started independently collecting rare birds in 1843, for both scientific and artistic purposes. His exact observations were reflected in his well-written, famous book "Die Vogelwarte Helgoland" (Gätke, 1891); the second edition with drawings by the author and additions by Rudolf Blasius, was fortunately reprinted on the initiative of Gottfried Vauk in 1987, and is still available. We are also very much indebted to Herbert Ringleben for his evaluation of this book and his comments on the observation of some rare birds on Helgoland (Ringleben, 1969). The book consists of three parts. The first deals with the migration of birds (2nd. ed., 3-153), the second with the changing of colours without moult (157-170), and the last and most important is a catalogue of about 400 species of birds seen on Helgoland (173-636). The term "Vogelwarte" - created by Gätke between 1879 and 1883, probably as an analogy to "Sternwarte", (Ringleben, 1958) - became very popular and was adopted in 1901 by Johannes Thienemann (1863-1938), the founder of the "Vogelwarte Rossitten" (Thienemann, 1927). Even before the island became part of the German Reich in 1890, Gätke had, for private reasons, been negotiating the sale of his bird collection with the British Museum of Natural History in London.

Archival research by Dr. Petra Werner has thrown new light on the circumstances of how the Prussian State succeeded in purchasing this wonderful collection for the amount of thirteen thousand Marks. This collection, as well as Gätke's other botanic and 
zoological collections, and, at a later date, Gätke's private library, provided the newlyfounded Biologische Anstalt Helgoland with a valuable and useful scientific foundation.

The purchase in 1891 (for the contract, dated 16th February 1891, see Fig. 1), following the offer dated 22nd October 1890, (Fig. 2), has to be understood in the context of the rise of marine biology in the mid-19th century which led to the foundation of biological institutes on the coast, following the example of the famous Zoological Station established at Naples in 1872 by Anton Dohrn (1840-1909). In June 1876, the zoologist Ernst Ehlers (1835-1925) from Göttingen forwarded a proposal (for a station) to the Prussian Minister of Culture, Adalbert Falk (1827-1900). Independently of this, the meeting of the "Gesellschaft Deutscher Naturforscher und Ärzte" in Hamburg presented a similar project in the same autumn, which was supported not only by the highly influential botanist Nathanael Pringsheim (1823-1894), but also by the "Deutscher Fischerei-Verein". As Dr. Werner points out in a recent publication (Werner, 1992) and in her book on the history of the "Biologische Anstalt Helgoland" (Werner, 1993), Anton Dohrn tried to prevent the foundation of this station, suspecting competition with his own station. In any case, in July 1890 the former plan was taken up again by Pringsheim, the zoologist Franz Eilhard Schulze (1840-1917), the anatomist Oscar Hertwig (1849-1922), and others in Berlin. This time they were successful, on the strength of scientific, economic and national arguments. As ichthyological research seemed very necessary for the benefit of German sea-fishery, the zoologist Friedrich Heincke (1852-1929), excellent specialist on the herring, was appointed as first director of the "Biologische Anstalt Helgoland" in 1892. The position of zoological assistant was given to Clemens Hartlaub (1858-1927), the son-in-law of Ernst Ehlers. Although he was the son of the well-known ornithologist Gustav Hartlaub (1814-1900) in Bremen and had extensive knowledge of Coelenterata, Echinodermata, and Mammals, he unexpectedly did no ornithological research on the island. He published only a short note "Über die Gätke'sche Vogelsammlung" (Hartlaub, 1894). Therefore Hartlaub did not really replace Gätke even after the latter's death in January 1897. So Gätke's heritage was neglected until Hugo Weigold (1886-1973) came to the island in 1909. Weigold very soon switched his scientific interest from Crustacea to ornithology, because, like Gätke, he was fascinated by the migration of birds. He was the right man in the right place! In 1910, he presented the paper "Die Vogelwarte Helgoland einst und jetzt und die Methoden der Vogelzugforschung" at the Fifth International Congress on Ornithology in Berlin (Weigold, 1911). He also published four reports on his ornithological activities, the "Jahresberichte der Vogelwarte der (Kgl.) Biologischen Anstalt auf Helgoland", from 1910 to 1913, and again from 1922 to 1925 , after the "Vogelwarte" had recovered from the damage caused during the First World War (Weigold, 1910-1925). The events of this period were described in a short article (Mielck, 1919), written by Wilhelm Mielck (1879-1933), later director of the station from 1921 to his death in 1933. Weigold himself was abroad in East Asia, where he was stranded after an expedition there with Walter Stötzner, and where he remained from 1914 to 1916, cut off from Helgoland by the war. When he returned in May 1919, he wrote a very interesting report, the "Bericht über seine Tätigkeit während seines Urlaubs vom Nov. 1913 bis 16. Mai 1919", which is preserved in the Central Archives of the State of Merseburg. I am indebted to Dr. Werner for a xerox copy of this paper. After some remarks on the value of biogeography in terms of its comprehensiveness, the report starts 
by deriving the need for expeditions from his personal interests and his research done on Helgoland:

"I am a biogeographer and, first and foremost of course, a zoogeographer. And as noone these days can cover this field completely, I have chosen ornithology again, as my special field of investigation. But even with international marine science, in whose service I first came to Helgoland, it was the zoogeographical aspect that attracted me. Very decidedly the great, almost insoluble problem of bird migration belongs to this area of research, and it was to this that I then devoted myself. I might have been discouraged by the sheer vastness of this problem, like many others before me, if I had not gained through extensive travels, step by step, perception and, through that, possibilities for understanding. I first studied phenology in a classical place: Helgoland; I then followed the course of migrating birds that I had already mapped out by marking experiments. I myself became a migrating bird, to learn to understand them; romped in an aeroplane amongst them, in order to see with their eyes. But was there perhaps a possibility that this small corner of the earth, Helgoland, gave a false impression of the phenomenon? In order to check this, I watched the flocks migrating over me in Hungary, in the desert of Mesopotamia, on the coasts of the Atlantic Ocean and the Mediterranean, and, finally, in every corner of vast China. "1

This text needs no comment, but I would like to add that, according to some documents, Weigold used two aeroplanes for observing migrating birds in 1921. His successor as ornithologist, Rudolf Drost (1892-1971), continued this research, at least from 1927 on. The main method of recognizing individual birds was to ring them using aluminium rings (Bub \& Oelke, 1981), a method invented in the last decade of the 19th century by the Danish schoolteacher Hans Christian Cornelius Mortensen (1856-1921) (Stresemann, 1951, 341-342). Therefore, it was necessary to catch birds alive in a special trap (Sunkel, 1956). Early in 1908, Heincke made a proposal to the government concerning the layout of a botanical garden for the experiments of acclimatization planned by the botanist Paul Kuckuck (1866-1919); also in order to trap birds in the same place. In another proposal concerning the budget of 1911 (dated 23rd July 1910, demanding seven thousand Marks for the same purpose), the argumentation for needing a garden is based on the pending loss of private ground leased since 1908. The document mentions that the main problem concerning the preservation of the "Vogelwarte" was the fact that the island was being changed into a fortress. The new place proposed for the garden - the so-called "Sapskuhle" - was favourable because it was already in the possession of the state and situated in the military area. In an additional note, Kuckuck and Weigold explain the special value of the place for botanical experiments, was well as its suitability as a protected place for resting birds. Mentioning the enclosed paper (Weigold, 1910), the authors write:

"Helgoland - a natural monument that is the only one of its kind in the whole world is in jeopardy. In the words of the famous ornithologist Heinrich Gätke, the island $\mathrm{w}$ a $\mathrm{s}$ an ornithological station - a more propitious area could not have been thought of. Every year, especially at the time of the spring- and autumn-migrations, innumerable flocks of birds rest here; approximately 400 species - among these a great many rare and exotic accidentals that are otherwise not, or seldom, seen in Germany could be observed here and studied with regard to the peculiarities of their migratory habits. Already today, observations on the scale that Gätke engaged in are no longer 
128

Ch. Hünemörder

onsteifes

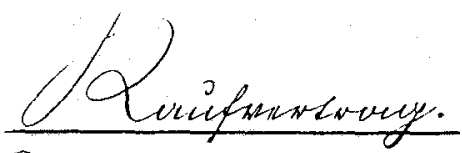

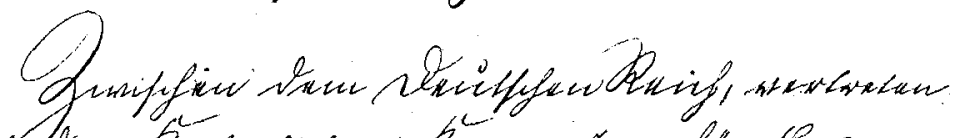

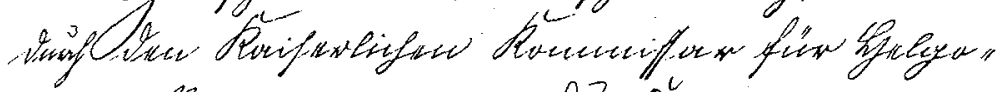

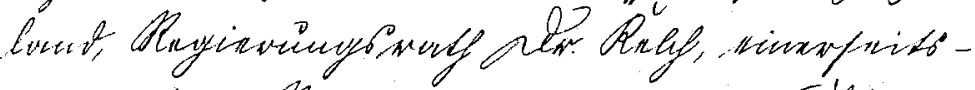

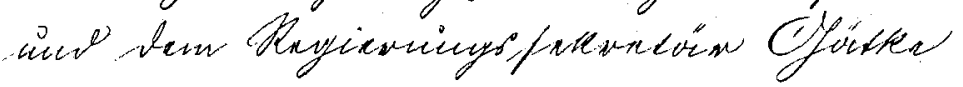

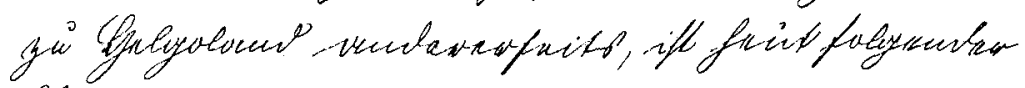

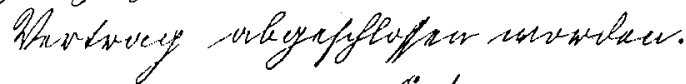

o.?

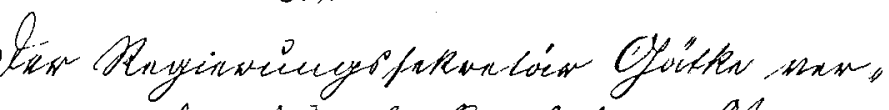

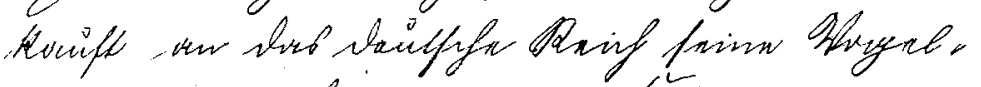

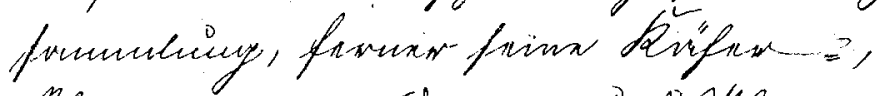

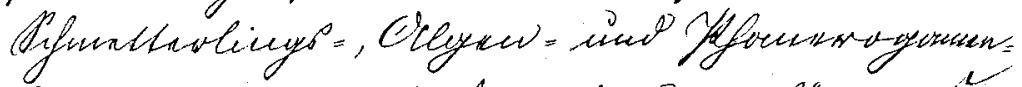

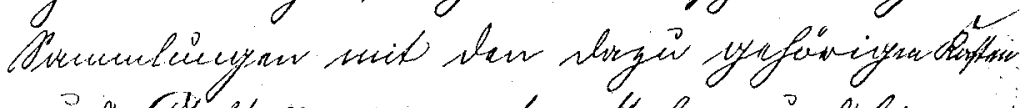

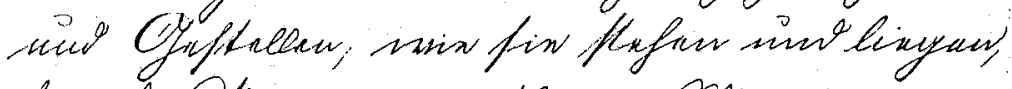

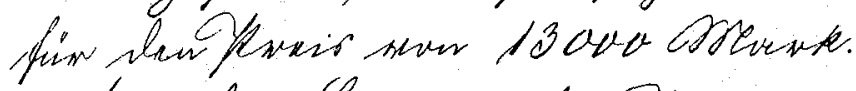

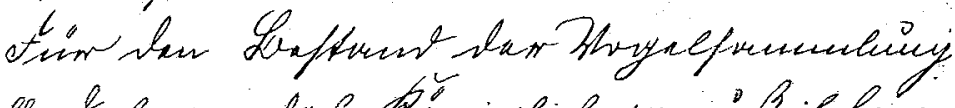

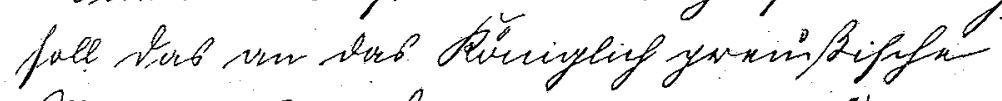

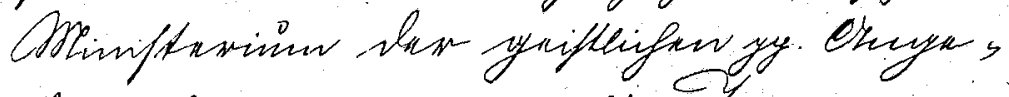

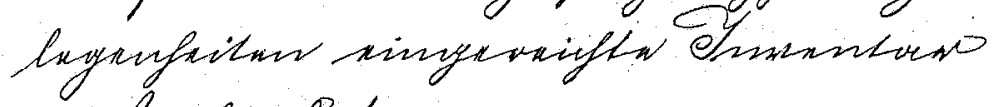
monbyabieno faim.

of 2 .

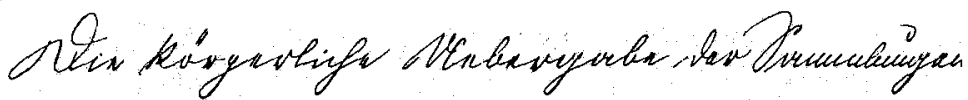

colote.

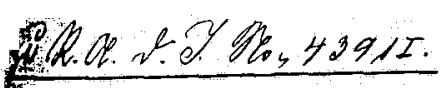


Ornithology on Helgoland

129

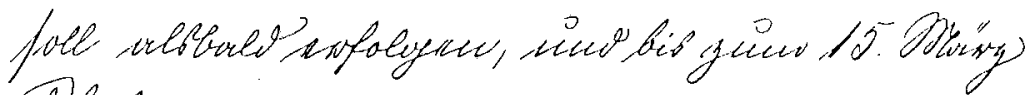
Pf. Annulet mandan.

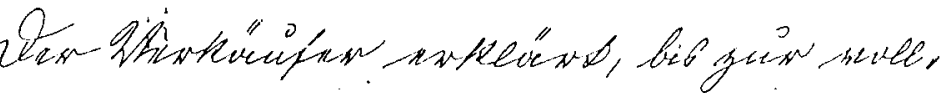

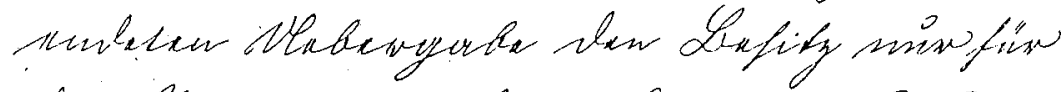

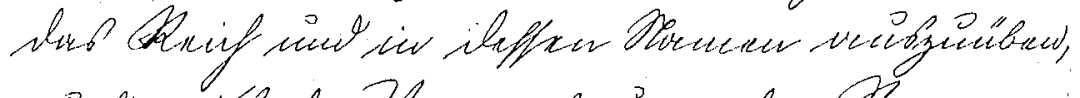

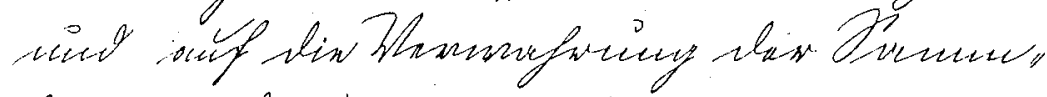

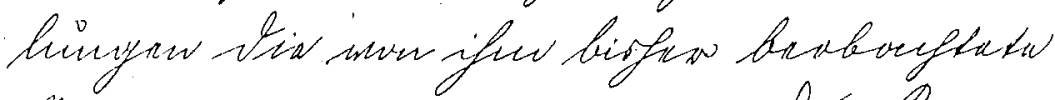

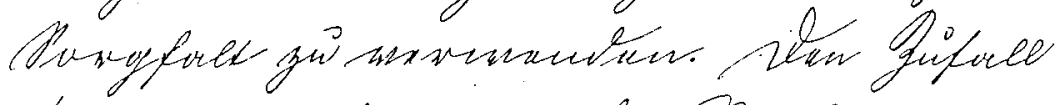

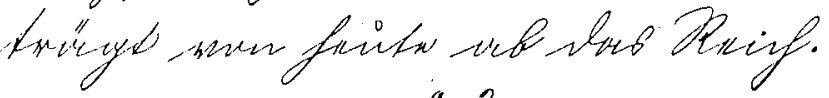

es. e?.

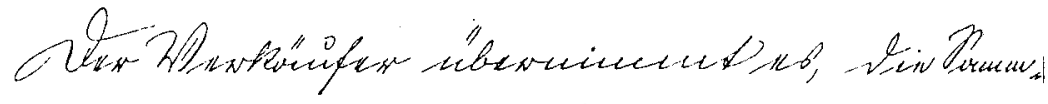

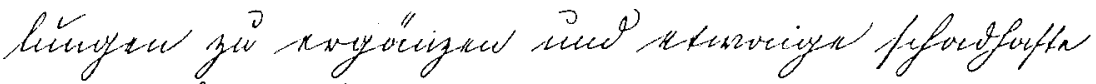

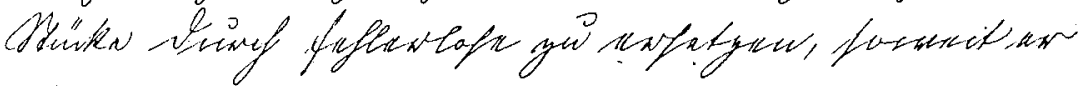

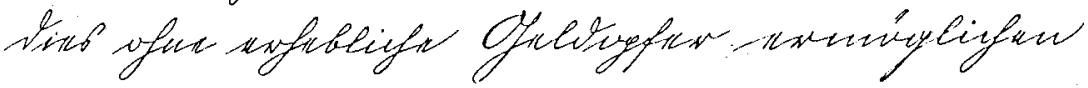
Hermes.

S. 4

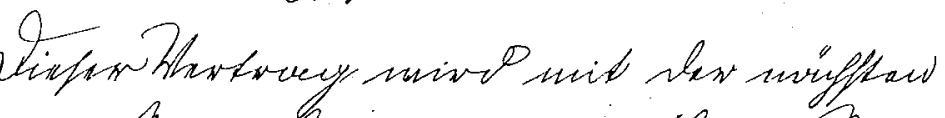

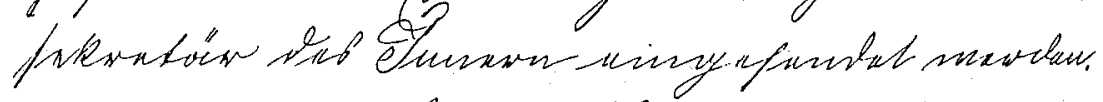

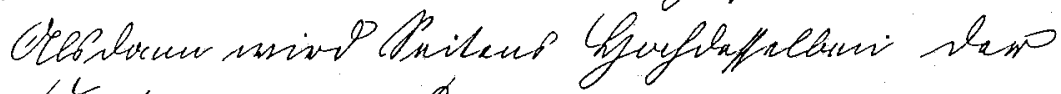

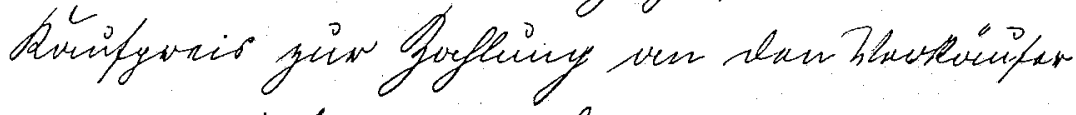

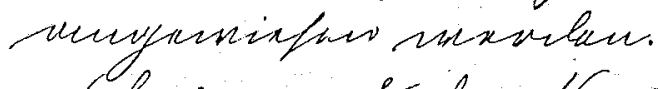

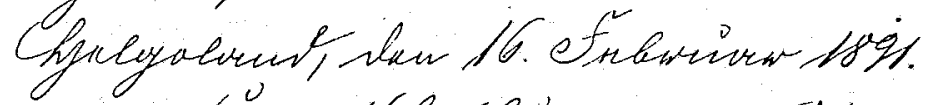

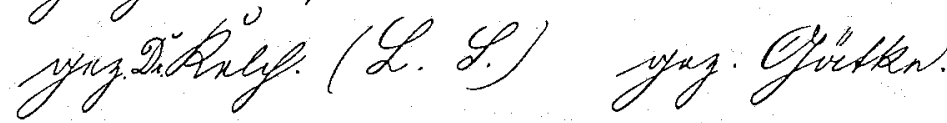

Fig. 1. Copy of the contract of purchase from February 16th, 1891, signed by Dr. Kelch and Gätke 


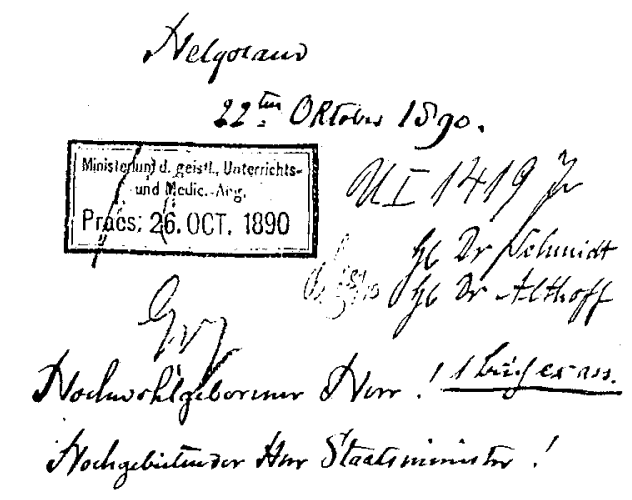

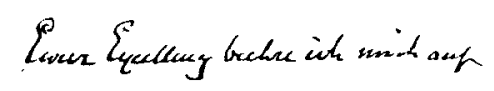

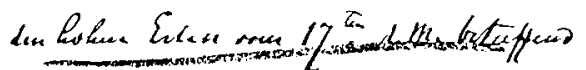

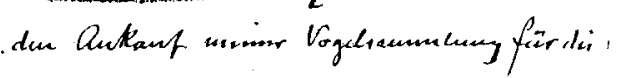

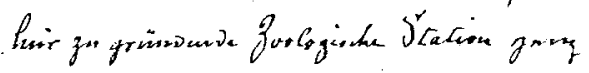

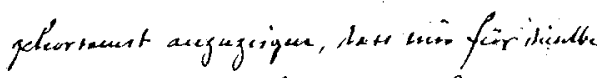

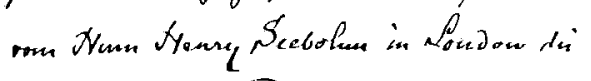

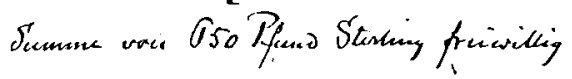

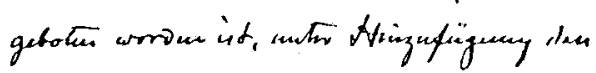

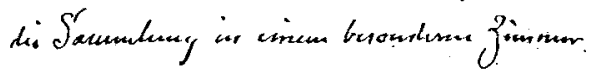

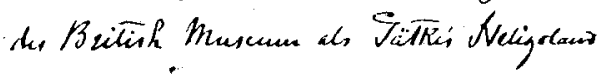

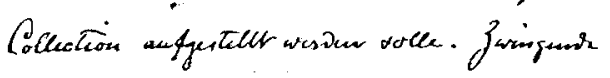

an

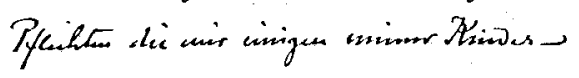

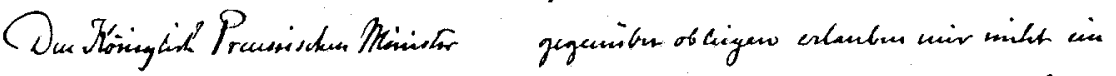

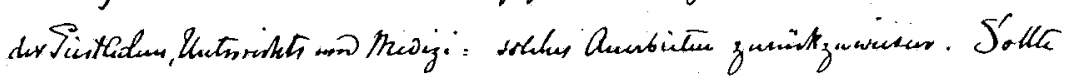

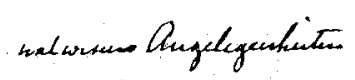

Xerr, Jevor, Gowker

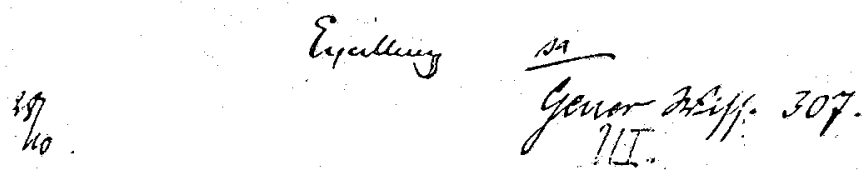




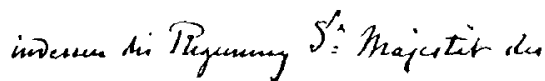

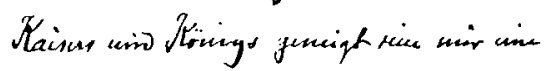

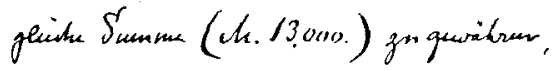

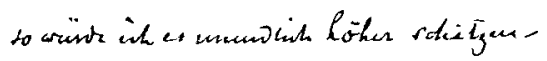

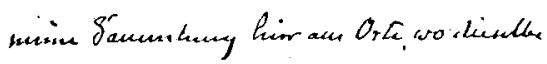

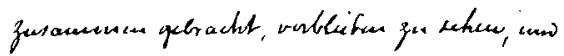

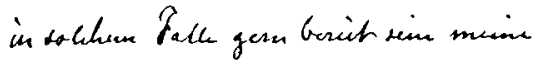

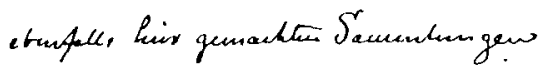

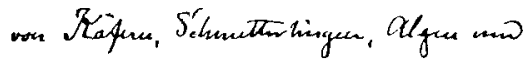

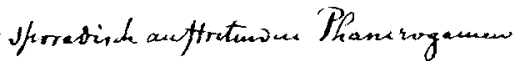

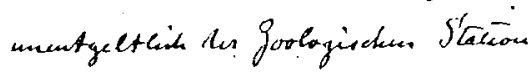
in dear Raupf gon gebure.

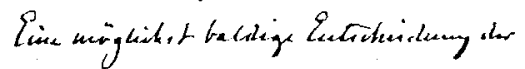

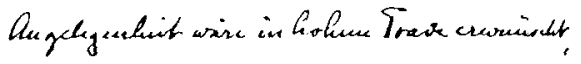

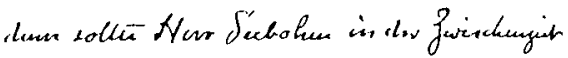

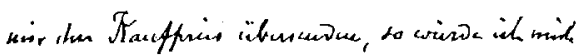

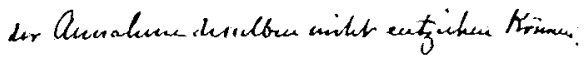

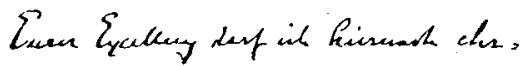

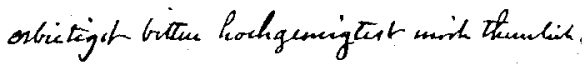

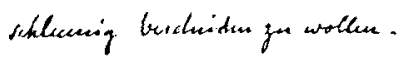

Enow Eyallay

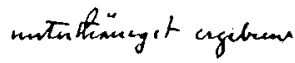

$$
\begin{aligned}
& \text { Ax. Sätu, }
\end{aligned}
$$

Fig. 2. Gätke's letter of October 22nd, 1890, to the Prussian Minister of Culture Gustav von Gossler $(1838-1902)$ 
possible. The ever-increasing building and heavy tratfic have already driven away many species; made their resting periods impossible or certainly shortened." ${ }^{2}$

Fortunately, the plan was realized, and so Weigold was able to increase the number of bird-skins, which had been firstly carefully described by him, and had already reached a total of four hundred and eight specimens, representing one hundred and fifty species. Before the war, more than ten thousand birds were marked in the garden; and from 1911 on, they were marked with individual rings. Weigold published many important papers, e.g. on the size and weight, in relation to age and sex, of migrating birds (Weigold, 1926) and also a comprehensive calendar of migration on Helgoland (Weigold, 1930). His "opus magnum", a detailed atlas on migration based on international cooperation, was composed in collaboration with Ernst Schüz (1901-1991) (cf. Berthold, 1991; Zink, 1991) who had worked with him for some time in the Zoological Department of the Museum of Natural History in Hannover, where Weigold had become director in 1924 (Kumerloeve, 1974; Schüz, 1973). Due to the poor state of the economy, it was not printed until 1931 (Schüz \& Weigold, 1931).

Weigold's successor on Helgoland, Rudolf Drost (1892-1971), managed to obtain better working conditions for the department "Vogelwarte Helgoland", which was established in 1923, and moved to a new building in 1926. Thus, Drost was in a position to organize many courses for students and other helpers, and to build up a network of observation-posts on the coast. The results of observations on an enormous number of ringed birds on Helgoland and elsewhere in the years between 1930 to 1944 are very well-documented in a special publication (Bub \& Klings, 1981). Drost himself carried out a very good propaganda campaign for his institution by way of numerous shorter articles (e.g. Drost, 1934). He also began to study the physiological activity of migrating birds, e.g. in a Faraday-cage, and carried out displacement experiments (cf. Wiltschko, 1989) to learn under what conditions, and over what distances, birds were able to return. During the war, he even used the new radar system, discovering that birds can perceive ultrasonic waves (Goethe, 1972). In addition to all these scientific activities, his enthusiasm attracted and encouraged many young ornithologists and other guestresearchers. He also supported ecological studies on populations of breeding seabirds on other islands and on the coast - as did also Friedrich Goethe, when studying the population of the herring gull at Memmert in the late 'thirties (Goethe, 1937). This field of research remains so important that in 1982, a special volume was published bearing the title "Vogelzug-Forschung und Seevogel-Ökologie" (Hartwig, 1982). After the Second World War, when the "Vogelwarte Helgoland" was re-established as an independent institute at Wilhelmshaven, Goethe became Drost's successor (1958), while from 1954 on. the "Inselstation" had its own scientific head of department.

To sum up, I would like to say that the ornithological research carried out on Helgoland before 1945 forms the basis for today's sophisticated studies and experiments, and we are very much indebted to all the ornithologists who contributed thereto in the past. The unspoken key-words of my short paper - continuity and change - can be improved by reading original papers, such as the publication "Der Zug des Sperbers (Accipiter nisus) auf Helgoland" (Moritz \& Vauk, 1976); as well as by studying all the valuable historical sketches already published (e.g. Drost, 1956; Vauk et al., 1977; Vauk \& Moritz, 1979). This brief survey, however, does not intend to throw new light on the 
historiography of ornithology on the island before 1945 but only to draw attention to it, once more.

Acknowledgements. For archival material I am very much indebted to Dr. P. Werner, Berlin; to the Stiftung Preußischer Kulturbesitz, for the permission of publication of the documents (Figs 1-4); and for translation of the German passages and critical revision of the English text, to Carol Berger and Andy Godfrey, Hamburg.

\section{NOTES}

1 "Ich bin Biogeograph, in erster Linie natürlich Tiergeograph. Und da heutzutage niemand mehr alles genau umfassen kann, wählte ich mir als Sondergebiet wieder die Vogelkunde als Gegenstand. Aber auch schon bei der internationalen Meeresforschung, in deren Dienst ich ursprünglich nach Helgoland kam, hatte mich die tiergeographische Seite angezogen. Viel ausgesprochener gehört diesem Forschungsgebiet aber das große, schier unerschöpfliche Problem des Vogelzugs an, dem ich mich dann widmete. Ich wäre wohl ebenso entmutigt davon wieder abgegangen wie manche andre vor mir, wenn ich nicht durch ausgibige Reisen mir nach und nach Anschauung und dadurch Erkenntnismöglichkeit beschafft hätte. Ich studierte die Phänologie erst an einer klassischen Stätte: Helgoland, folgte dann aber den Wandervögeln auf ihren Wegen, die ich durch den Markierungsversuch festgelegt hatte, wurde selbst ein Wandervogel, um sie verstehen zu lernen, und tummelte mich im Flugzeug unter ihnen, um mit ihren Augen sehen zu lernen. Denn gab nicht vielleicht der eine Fleck Helgoland ein falsches Bild? Um das zu prüfen, sah ich den Wanderzug an mir vorüberrauschen in Ungarn und in der Wüste Mesopotamiens, an den Küsten des Atlantiks und des Mittelmeers und nun an allen Ecken des gewaltigen China." (Weigold, 1910-1929, fol. 146-147)

2 "In Helgoland steht ein Naturdenkmal auf dem Spiel, das in seiner Art einzig auf der ganzen Erde ist. Die Insel war nach dem Ausdruck des berühmten Ornithologen Heinrich Gätke eine Vogelwarte, wie sie günstiger gar nicht gedacht werden kann. Alljährlich besonders zur Zeit des Frühjahrs- und Herbstzuges rasten hier unzählige Scharen von Vögeln; gegen 400 Arten, darunter zahlreiche seltene, in Deutschland nicht oder kaum beobachtete und exotische Irrlinge kamen hier zur Beobachtung und konnten in ihren Eigentümlichkeiten hinsichtlich ihrer Zuggewohnheiten studiert werden. Schon heute sind nun Beobachtungen in dem Umfange, wie sie Gätke anstellte, nicht mehr möglich. Die immer mehr um sich greifende Bebauung und der starke Verkehr haben manche Arten bereits verscheucht, ihre Rast unmöglich gemacht oder doch verkürzt." (Kuckuck \& Weigold, 1910, fol. 76 recto)

\section{ARCHIVAL SOURCES}

Gätke, H.: Letter to the Kgl. Preuss. Minister der Geistlichen, Unterrichts und Medizinalwesen Angelegenheiten Herrn Dr. von Gossler Excellenz from October 22nd., 1890, and Copy of "Kaufvertrag" from February 16th, 1891. Stiftung Preußischer Kulturbesitz, Dienststelle Merseburg, Preußisches Kultusministerium, Rep. 76 Vc Sekt. 1 Tit. XI, Generalia, Wissenschaftssachen, wissenschaftliche Sachen, Teil II, Nr.10e, Die Gaetkesche Vogelsammlung, das NordseeMuseum auf Helgoland und die Vogelwarte daselbst, Bd. 1 (1890-1909), Bl. 7 bzw. 25.

Kuckuck, P. \& Weigold, H.: Anlage 1 zu A.323 vom 23. Juli 1910. Erläuterungen zum Plane eines botanisch-ornithologischen Versuchsgartens auf Helgoland. Merseburg (see Gätke), Nr. 10g, A. 323, Der botanische Versuchsgarten bei der Biologischen Anstalt Helgoland, Bl. 75-78.

Weigold, H.: Bericht über seine Tätigkeit während seines Urlaubs vom Nov. 1913 bis 16. Mai 1919. Merseburg (see Gätke), Bd. 2 (1910-1929), Bl. 146-169. 


\section{LITERATURE CITED}

Berthold, P., 1991. Prof. Dr. Ernst Schüz (1901-1991). - J. Orn. 132, 461-463.

Bub, H. \& Klings, M., 1981. Die Vogelberingung auf Helgoland von 1930 bis $1944 .-$ Abh. Vogelfang, Vogelberingung $8,1-216$.

Bub, H. \& Oelke, H., 1981. Zur Geschichte der Vogelmarkierungen bis zu den Anfängen der wissenschaftlichen Vogelberingung. - J. Orn. 122, 341-357.

Drost, R., 1934. Die Vogelwarte Helgoland (Abteilung der Staatlichen Biologischen Anstalt). Biologe 3, 184-186.

Drost, R., 1956. Geschichte der Vogelwarte Helgoland. In: Natur und Jagd in Niedersachsen. Hrsg. von F. Steiniger. Hannover, 12-32.

Gätke, H., 1900. Die Vogelwarte Helgoland. Meyer, Braunschweig. (Repr. 1987: Knauß, Helgoland, 654 pp.)

Goethe, F., 1937. Beobachtungen und Untersuchungen zur Biologie der Silbermöwe (Larus argentatus Pontopp.) auf der Vogelinsel Memmertsand. - J. Orn. 85, 1-119.

Goethe, F., 1972. Rudolf Drost 1892-1971. - J. Orn. 113, 219-225.

Hartlaub, C., 1894. Über die Gätke'sche Vogelsammlung. - Orn. Mber. 2, 143-145.

Hartwig, E. (Hrsg.), 1982. Vogelzug-Forschung und Seevogel-Ökologie. - Seevögel (Sonderbd) 5 , $1-165$.

Kumerloeve, H., 1974. Hugo Weigold in memoriam. - J. Orn. 115, 234-235.

Mielck, W., 1919. Über das Schicksal der Helgoländer Biologischen Anstalt im Kriege und die Wiederaufnahme ihrer Tätigkeit nach Friedensschluß. - Fischerbote 11, 184-189.

Moritz, D. \& Vauk, G., 1976. Der Zug des Sperbers (Accipiter nisus) auf Helgoland. - J. Orn. 117, $317-328$.

Ringleben, H., 1958. Zur Entstehungsgeschichte der Bezeichnung "Vogelwarte". - Vogelwarte 19, 206-207

Ringleben, H., 1969. Bemerkungen zu Heinrich Gätkes Buch "Die Vogelwarte Helgoland" und über das Vorkommen einiger seltener Vögel auf Helgoland. - Bonn. zool. Beitr. 20, 211-218.

Schüz, E., 1973. Hugo Weigold 1886-1973. - Vogelwarte 27, 141-145.

Schüz, E. \& Weigold, H., 1931. Atlas des Vogelzugs nach den Beringungsergebnissen bei paläarktischen Vögeln. - Abh. Geb. Vogelzugsforschung 3, 1-160.

Stresemann, E., 1951. Die Entwicklung der Ornithologie von Aristoteles bis zur Gegenwart. Limberg, Aachen, $431 \mathrm{pp}$.

Stresemann, E., 1967. Vor- und Frühgeschichte der Vogelforschung auf Helgoland. - J. Orn. 108, $377-429$.

Sunkel, W., 1956. Der Vogelfang des Ornithologen. - J. Orn. 97, 73-89.

Thienemann, J., 1930, 1927, Rossitten. Drei Jahrzehnte auf der Kurischen Nehrung. Neudamm, $332 \mathrm{pp}$.

Vauk, G. \& Moritz, D. (Hrsg.), 1979. Festschrift zum 25jährigen Bestehen der Inselstation Helgoland des Instituts für Vogelforschung "Vogelwarte Helgoland". - Abh. Geb. Vogelkunde 6, 1-327.

Vauk, G., Bindig, W., Goethe, F. \& Gruner, D., 1977. Die Geschichte der Vogelwarte und der Vogelforschung auf der Insel Helgoland. Niederelbe Verl., Otterndorf, $160 \mathrm{pp}$.

Weigold, H., 1910. Was soll aus der Vogelwarte Helgoland werden? - Orn. Mschr. 35 (1), 1-64.

Weigold, H., 1910-1925. Jahresbericht der (Kgl.) Biol. Anstalt Helgoland 1-8.- J. Orn. 58, 1910 - 73, 1925 .

Weigold, H., 1911. Die Vogelwarte Helgoland einst und jetzt und die Methoden der VogelzugForschung. - Ber. int. Orn. Kongr. 5, 564-574.

Weigold, H., 1926. Maße, Gewichte und Zug nach Alter und Geschlecht bei Helgolander Zugvögeln. - Wiss. Meeresunters. (Helgoland) 15 (Abh. Nr. 17), 1-73.

Weigold, H., 1930. Der Vogelzug auf Helgoland, graphisch dargestellt. - Abh. Geb. Vogelzugsforschung 1 .

Werner, P., 1992. Anton Dohrn und die Gründung der Biologischen Anstalt Helgoland. - Hist. meeresk. Jb. $1,45-54$.

Werner, P., 1993. Die Gründung der Königlichen Biologischen Anstalt auf Helgoland und ihre Geschichte bis 1945. - Helgoländer Meeresunters. 47 (Suppl.), 1-182.

Wiltschko, R, 1989. Aus der Geschichte der Orientierungsforschung. - J. Om. 130, 399-421.

Zink, G., 1991. In Erinnerung an Ernst Schüz, 1901-1991. - Vogelwarte 36, 163-165. 